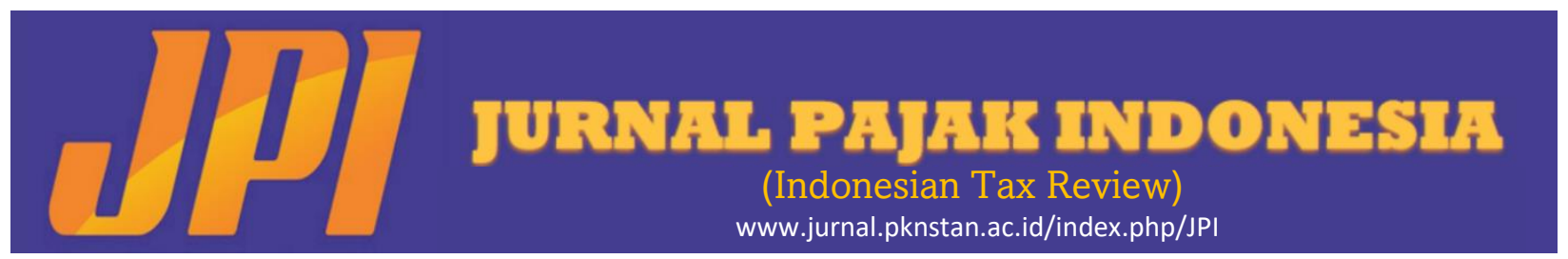

\title{
MENGKAJI PRAKTIK PEMBLOKIRAN HARTA KEKAYAAN PENANGGUNG PAJAK (STUDI DI KANTOR PELAYANAN PAJAK PRATAMA MADIUN)
}

\author{
Nikita Puspa Wisiswa \\ Politeknik Keuangan Negara STAN \\ Irwan Aribowo \\ Politeknik Keuangan Negara STAN
}

Alamat Korespondensi: 2301190066.nikitapuspa@gmail.com

INFORMASI ARTIKEL
Diterima Pertama
[20082021]
Dinyatakan Diterima
[04112021]
KATA KUNCI:
Perpajakan, Penagihan, Pemblokiran, Akses
Informasi Keuangan.

KLASIFIKASI JEL:

$\mathrm{H} 2 \mathrm{O}$

\begin{abstract}
ABSTRAK
One of the efforts to reduce tax arrears is through tax collection in the form of account blocking. The implementation of Perpu Number 1 of 2017 concerning Access to Financial Information for Tax Purposes also has an impact on the output and outcome of the account blocking process. The obstacles that occurred during the blocking came from the banking and tax guarantor side, from the bank side mostly caused by dissimilarity of understanding and policies related to account blocking between the Directorate General of Taxes and the Bank, while from the tax guarantor side generally is in the form of changes in the deed during the blocking process, bankruptcy and/or death of the tax bearers. In its efforts to prevent and overcome these obstacles, there is also a Letter from the Director General of Taxes Letter Number 20 of 2018 concerning Confirmation of the implementation of Blocking, Prevention, and hostage taking.
\end{abstract}

Salah satu upaya untuk mengurangi tunggakan pajak adalah melalui tindakan penagihan pajak berupa pemblokiran. Pelaksanaan Perpu Nomor 1 tahun 2017 tentang Akses Informasi Keuangan untuk Kepentingan Perpajakan juga memberikan dampak bagi output dan outcome proses pemblokiran. Kendala-kendala yang terjadi selama pemblokiran berasal dari sisi perbankan dan penanggung pajak, dari sisi bank sebagian besar disebabkan oleh ketidakseragaman pemahaman dan kebijakan terkait pemblokiran antara Direktorat Jenderal Pajak dengan Bank, sedangkan dari sisi penanggung pajak umumnya berupa perubahan akta selama proses blokir, penanggung pajak pailit, bangkrut, maupun meninggal dunia. Kemudian dalam rangka mencegah dan mengatasi kendala yang ada, terdapat juga Surat Direktur Jenderal Pajak Nomor 20 tahun 2018 tentang Penegasan atas pelaksanaan Pemblokiran, Pencegahan, dan Penyanderaan. 


\section{PENDAHULUAN}

Dalam rangka menghimpun penerimaan negara melalui pajak, Pemerintah Indonesia telah memberikan kemudahan dengan memberikan kepercayaan penuh kepada masyarakat untuk menghitung, memperhitungkan, menyetor, dan melaporkan pajaknya sendiri secara self assessment (Susi Zulvina, 2017). Satu hal yang menjadi kunci utama dari self assessment system adalah kepatuhan sukarela para wajib pajak (Harahap, 2004). Sayangnya, ketidakpatuhan wajib pajak di Indonesia masih tergolong cukup tinggi. Dilansir dari kemenkeu.go.id pada Rabu (8/1/2020) realisasi pendapatan negara yang berasal dari perpajakan hanya sebesar Rp1.545 triliun (86,5\% dari target Anggaran Pendapatan dan Belanja Negara (APBN) Tahun 2019), dan jumlah wajib pajak yang melaporkan Surat Pemberitahuan (SPT) Tahunan dalam laporan tahunan Direktorat Jenderal Pajak (DJP) tahun 2019 hanya sebanyak 13.394.502, atau sekitar $73,06 \%$ dari total 18.334 .683 wajib pajak terdaftar wajib SPT Ketidakpatuhan penyetoran maupun pelaporan yang cukup tinggi ini bisa berasal dari ketidakmampuan wajib pajak untuk melunasi utang pajaknya, atau bahkan penghindaran pajak, sehingga hal ini yang menyebabkan tingginya tunggakan pajak (Nasution \& Aliffioni, 2018).

Sebagai upaya untuk mengurangi tunggakan pajak dan mengatasi ketidakpatuhan wajib pajak, maka dilakukanlah tindakan penagihan pajak sebagaimana diatur dalam Undang-Undang Nomor 19 tahun 1997 sebagaimana telah diubah terakhir dengan UndangUndang Nomor 19 tahun 2000 tentang Penagihan Pajak dengan Surat Paksa (UU PPSP). Salah satu tindakan yang dapat dilakukan dalam penagihan pajak adalah penjualan terhadap barang yang telah disita. Penjualan ini dilakukan melalui penjualan terbuka (lelang) kecuali untuk harta berupa uang tunai, deposito, tabungan atau bentuk lain yang dipersamakan dengan itu, obligasi, saham atau surat berharga lainnya, piutang, dan penyertaan modal pada perusahaan lain yang harus dilaksanakan dengan pemblokiran terlebih dahulu.

Kasus terkait pemblokiran yang akhir-akhir ini terjadi berkaitan dengan keterbukaan informasi keuangan untuk tujuan perpajakan. Dikutip dari news.ddtc.co.id pada Jumat (25/09/2020) bahwa pemenuhan permintaan informasi dan/atau bukti atau keterangan (IBK) dari DJP masih sangat minim, yaitu sebesar $4,3 \%$ dari total 70.000 surat permintaan IBK. Padahal, berdasarkan pasal 2 ayat (1) dan (2) PMK Nomor 70 tahun 2017 sebagaimana telah diubah dengan PMK Nomor 19 tahun 2018 tentang Petunjuk Teknis mengenai Akses Informasi Keuangan untuk Kepentingan Perpajakan disebutkan bahwa Dirjen Pajak berwenang mendapatkan akses informasi baik secara otomatis maupun berdasarkan permintaan.

Rendahnya tingkat pemenuhan permintaan tersebut kemudian menjadi masalah bagi pelaksanaan pemblokiran dalam rangka penagihan pajak, karena tindakan ini sangat memerlukan informasi keuangan wajib pajak. Permasalahan ini menjadi fenomena yang menarik dan ingin penulis angkat, terutama pelaksanaannya di Kantor Pelayanan Pajak Pratama Madiun. Alasan dipilihnya KPP Pratama Madiun adalah adanya tindakan pemblokiran serentak atas harta kekayaan beberapa perusahaan oleh KPP Pratama Madiun setelah terbitnya Perpu Nomor 1 tahun 2017 tentang Akses Informasi Keuangan Untuk Kepentingan Perpajakan. Pemblokiran serentak ini dilakukan atas seluruh akses ekonomi penanggung pajak yang memiliki hubungan istimewa secara keluarga, yaitu hubungan ketergantungan antar wajib pajak yang disebabkan oleh adanya hubungan darah atau perkawinan.

Alasan selanjutnya dikarenakan jumlah bank di wilayah Madiun cukup banyak. Sebagaimana dikutip dari website Pemerintah Kota Madiun (madiunkota.go.id) pada Sabtu (17/06/2017), Kepala perwakilan Bank Indonesia Kediri, Joko Raharto menjelaskan pertimbangan BI membuka kas titipan di Kota Madiun adalah banyaknya kantor cabang di wilayah Madiun dan pertumbuhan ekonominya yang cukup tinggi dalam 5 tahun terakhir. Namun, banyaknya bank di Madiun rupanya tidak sejalan dengan jumlah pemenuhan permintaan blokir. Dari data seksi penagihan KPP Pratama Madiun, persentase pemenuhannya bahkan tidak mencapai $20 \%$ selama 3 tahun terakhir.

\section{KERANGKA TEORI}

\subsection{Teori}

\subsubsection{Penagihan Pajak}

Dalam UU PPSP Pasal 1 angka 9 disebutkan bahwa penagihan pajak adalah serangkaian tindakan agar penanggung pajak melunasi utang pajak dan biaya penagihan pajak dengan menegur atau memperingatkan, melaksanakan penagihan seketika dan sekaligus, memberitahukan surat paksa, mengusulkan pencegahan, melaksanakan penyitaan, melaksanakan penyanderaan, dan menjual barang yang telah disita.

\subsubsection{Pemblokiran}

Istilah pemblokiran umumnya digunakan oleh pengadilan untuk memerintahkan bank atau lembaga keuangan agar menempatkan suatu rekening yang berisi dana sebagai akun yang ditangguhkan, yang hanya dapat dicairkan atas perintah pengadilan atau lembaga yang diakui oleh pengadilan tersebut (Chloe Norris, 2017). Pemblokiran sendiri menjadi salah satu tindakan dalam proses penagihan pajak oleh pejabat yang bertujuan untuk memindahbukukan saldo rekening penanggung pajak ke kas negara (Sulistiriyanto, 2011).

\subsubsection{Harta Kekayaan Penanggung Pajak yang Tersimpan dalam Bank}

Secara bahasa, harta kekayaan adalah segala sesuatu yang diperoleh atau dikumpulkan oleh seseorang melalui suatu tindakan (Qodri, 2014), sedangkan penggunaan istilah harta kekayaan penanggung pajak yang tersimpan dalam bank terdapat pada Keputusan Menteri Keuangan Nomor 563 tahun 2000 tentang Pemblokiran dan Penyitaan 
Harta Kekayaan Penanggung Pajak yang Tersimpan pada Bank dalam rangka Penagihan Pajak dengan Surat Paksa dan peraturan pelaksanaannya yaitu Peraturan Direktur Jenderal Pajak Nomor 24 tahun 2014 tentang Tata Cara Pelaksanaan Pemblokiran dan Penyitaan Harta Kekayaan Penanggung Pajak yang Tersimpan pada Bank dalam rangka Penagihan Pajak dengan Surat Paksa. Dalam KMK ini, harta kekayaan penanggung pajak yang tersimpan pada bank meliputi rekening, simpanan, dan bentuk simpanan lain yang lazim dalam praktek perbankan

\subsubsection{Rahasia Bank}

Bank adalah lembaga keuangan yang keberadaannya bergantung penuh pada kepercayaan para nasabah yang memercayakan dana dan jasa lainnya melalui bank (Sjamsuddin, 2015). Kepercayaan masyarakat terhadap bank akan terjaga dan terus meningkat jika bank patuh terhadap kewajiban rahasia bank (Usman, 2010 dikutip dalam Jailani, 2019)

Rahasia bank menurut Pasal 1 angka 28 UndangUndang Nomor 10 tahun 1998 tentang perubahan atas Undang-Undang Nomor 7 tahun 1992 tentang Perbankan (UU Perbankan) adalah segala sesuatu yang berhubungan dengan keterangan mengenai nasabah penyimpanan dan simpanannya. Selanjutnya, kewajiban bank terhadap rahasia bank diatur dalam Pasal 40 ayat (1), kewajiban ini juga dipertegas dengan Pasal 2 ayat (1) Peraturan Bank Indonesia Nomor 2 tahun 2000 (Peraturan BI) yang menyatakan bank wajib merahasiakan segala sesuatu yang berhubungan dengan keterangan mengenai nasabah penyimpan dan simpanan nasabah. Namun, ketentuan rahasia bank tidak berlaku untuk kepentingan perpajakan sebagaimana disebutkan dalam Pasal 2 ayat (4) huruf a Peraturan Bl, dan pelaksanaannya diatur dalam Pasal 3 ayat (1) Peraturan $\mathrm{BI}$, yaitu harus terlebih dahulu memperoleh perintah atau izin tertulis untuk membuka rahasia bank dari pimpinan Bank Indonesia.

\subsubsection{Akses Informasi Keuangan untuk Kepentingan} Perpajakan

Istilah "akses" digunakan untuk mendefinisikan langkah pengumpulan dan/atau pengambilan informasi di lingkup digital (Astini, 2019). Istilah ini digunakan pula dalam bidang perpajakan, berdasarkan Pasal 1 Perpu Nomor 1 tahun 2017, Akses informasi keuangan untuk kepentingan perpajakan meliputi akses untuk menerima dan memperoleh informasi keuangan dalam rangka pelaksanaan ketentuan peraturan perundangundangan di bidang perpajakan dan pelaksanaan perjanjian internasional di bidang perpajakan.

Berlakunya Perpu Nomor 1 tahun 2017 yang ditetapkan melalui Undang-Undang Nomor 9 tahun 2017 sekaligus memperbaharui kewenangan DJP untuk dapat langsung meminta informasi keuangan wajib pajak dari lembaga jasa keuangan tanpa mekanisme izin dari Menteri Keuangan dan Otoritas Jasa Keuangan (Bandiyono \& Karimah, 2021). Kewenangan DJP ini memiliki 2 tujuan, pertama agar
DJP memperoleh informasi keuangan tentang penyimpanan dana oleh Warga Negara Asing (WNA) di Indonesia untuk diberikan ke negara asalnya, yang kedua adalah agar Pemerintah dapat memperoleh informasi keuangan dari rekening wajib pajak dalam negeri (Santoso, 2020).

\subsection{Penelitian Terdahulu}

\begin{tabular}{|c|c|c|}
\hline $\begin{array}{l}\text { Judul, Penulis, } \\
\text { Penerbit, Tahun }\end{array}$ & Fokus Studi & $\begin{array}{l}\text { Perbedaan dengan } \\
\text { Penelitian ini }\end{array}$ \\
\hline \begin{tabular}{|c|} 
Implementasi \\
Penagihan Pajak \\
Sesuai Undang- \\
Undang Nomor 19 \\
Tahun 1997 Jo. \\
Undang-Undang \\
Nomor 19 Tahun \\
2000 (Studi Pada \\
Kantor Pelayanan \\
Pajak Pratama \\
Mojokerto), Rachman \\
Bawono Sidiq \\
Saputra; Heru Susilo; \\
Arik Prasetya, Jurnal \\
Perpajakan (JEJAK), \\
2016
\end{tabular} & $\begin{array}{c}\text { Implementasi } \\
\text { penagihan pajak, } \\
\text { kendala, dan solusi } \\
\text { dalam menghadapi } \\
\text { kendala di KPP } \\
\text { Pratama Mojokerto } \\
\text { sebelum } \\
\text { diterbitkannya Perpu } \\
\text { Nomor } 1 \text { tahun } 2017 \\
\text { tentang Akses } \\
\text { Informasi Keuangan } \\
\text { untuk Kepentingan } \\
\text { Perpajakan }\end{array}$ & \begin{tabular}{|c|} 
Lebih memfokuskan \\
pada salah satu upaya \\
penagihan pajak \\
berupa pemblokiran \\
rekening, kendala \\
dalam \\
pelaksanaannya, \\
serta upaya untuk \\
mencegah dan \\
menghadapi kendala \\
terkait pemblokiran di \\
KPP Pratama Madiun \\
setelah \\
diterbitkannya Perpu \\
Nomor 1 tahun 2017 \\
tentang Akses \\
Informasi Keuangan \\
untuk Kepentingan \\
Perpajakan
\end{tabular} \\
\hline $\begin{array}{c}\text { Analisa Kinerja } \\
\text { Pelaksanaan } \\
\text { Penagihan Pajak Pada } \\
\text { KPP Pratama Kayu } \\
\text { Agung, Rusmida JH } \\
\text { Hutabarat, Jurnal } \\
\text { Kompetitif, } 2014\end{array}$ & $\begin{array}{c}\text { Efektivitas } \\
\text { Pelaksanaan } \\
\text { penagihan aktif di KPP } \\
\text { Pratama Kayu Agung } \\
\text { pada tahun } 2010 \\
\text { dengan cara } \\
\text { membandingkan rasio } \\
\text { realisasi terhadap } \\
\text { target }\end{array}$ & \begin{tabular}{|} 
Lebih memfokuskan \\
pada salah satu upaya \\
penagihan pajak \\
berupa pemblokiran \\
di KPP Pratama \\
Madiun dari tahun \\
2018 hingga 2020 dan \\
meninjau \\
pelaksanaannya pada \\
tahun tersebut
\end{tabular} \\
\hline
\end{tabular}

\section{METODE DAN TEKNIK PENGUMPULAN}

\section{DATA}

Pada penelitian ini, penulis menggunakan metode kualitatif, yaitu mengkonstruksi realitas dan memahami maknanya dengan memperhatikan proses, peristiwa dan otentisitas (Somantri, 2005). Sedangkan dalam mengumpulkan data, penulis menggunakan teknik yang meliputi:

\subsection{Studi Pustaka}

Penulis mengumpulkan data melalui sumber tertulis dengan cara membaca dan mempelajari buku, literatur, serta berbagai laporan yang berkaitan dengan masalah pemblokiran dan akses informasi keuangan untuk kepentingan perpajakan. Teknik ini bertujuan untuk memperoleh landasan teori terkait masalah yang akan penulis bahas

\subsection{Penelitian Lapangan}

Pengumpulan data dan informasi dalam metode ini dilakukan cara sebagai berikut:

\section{Wawancara}

Penulis melakukan wawancara langsung dengan jurusita pajak dan kepala seksi penagihan KPP Pratama 
Madiun untuk memperoleh data mengenai tata cara dan kendala pelaksanaan pemblokiran, serta upaya mencegah dan mengatasi kendala yang timbul selama proses pelaksanaan pemblokiran.

\section{Observasi}

Penulis mengumpulkan, mempelajari, dan mengolah data-data historis meliputi data pencairan tunggakan pajak dan data pemenuhan permintaan blokir dari tahun 2018 sampai dengan tahun 2020 serta memahami dokumen-dokumen penting yang erat hubungannya dengan objek penelitian.

Pengumpulan data di KPP Pratama Madiun dilakukan dari Bulan Maret hingga Bulan Mei 2021.

\section{HASIL PENELITIAN}

\subsection{Meninjau Pelaksanaan Pemblokiran di KPP Pratama Madiun}

KPP Pratama Madiun melaksanakan tindakan pemblokiran atas harta kekayaan yang tersimpan dalam bank berdasarkan Undang-Undang Nomor 19 tahun 2000 tentang Penagihan Pajak dengan Surat Paksa, Keputusan Menteri Keuangan Nomor 563 tahun 2000 tentang Pemblokiran dan Penyitaan Harta Kekayaan Penanggung Pajak yang Tersimpan pada Bank dalam rangka Penagihan Pajak dengan Surat Paksa, Peraturan Direktur Jenderal Pajak Nomor 24 tahun 2014 tentang Tata Cara Pelaksanaan Pemblokiran dan Penyitaan Harta Kekayaan Penanggung Pajak yang Tersimpan pada Bank dalam rangka Penagihan Pajak dengan Surat Paksa. Sedangkan terkait tata cara pelaksanaan pemblokiran, KPP Pratama Madiun berpedoman pada Peraturan Direktur Jenderal Pajak Nomor 24 tahun 2014.

Pada tahun 2017, diterbitkan Keputusan Menteri Keuangan Nomor 12 tahun 2017 tentang penetapan Aplikasi, Prosedur Pengajuan, Tata Naskah Dinas, Usulan Pembukaan Rahasia Bank Secara Elektronik. Aplikasi ini disebut dengan Akasia (Aplikasi Usulan Pembukaan Rahasia Bank), yaitu perangkat lunak sistem informasi pengelolaan usulan pembukaan rahasia bank yang berbasis jaringan untuk merekam, mengunggah dokumen pendukung, memberikan persetujuan, dan mencetak surat permintaan pembukaan rahasia bank, serta sebagai sarana informasi dan pemantauan permintaan pembukaan rahasia bank. Akasia terdiri dari modul pengajuan usulan pembukaan rahasia bank, modul pemrosesan usulan pembukaan rahasia bank di kantor pusat DJP, dan modul penyelesaian usulan pembukaan rahasia bank di sekretariat jenderal kementerian keuangan.

Akasia dinilai sangat bermanfaat bagi jurusita yang memerlukan permintaan IBK dalam proses pelaksanaan pemblokiran rekening wajib pajak, bahkan berdasarkan Nota Kesepahaman SP 22/DKNS/OJK/III/2017 antara OJK dengan DJP menyatakan bahwa waktu pemrosesan perintah pembukaan rahasia bank dipersingkat dari semula 6 bulan menjadi 2 minggu. Kasi Penagihan KPP Pratama Madiun juga menyebutkan bahwa aplikasi ini mempermudah jurusita untuk menentukan sasaran, karena dapat dengan cepat mengetahui seorang penanggung pajak memiliki rekening di bank apa, sehingga surat permintaan blokir hanya dikirim ke bank tersebut. Namun, dengan ditetapkannya Surat Edaran Menteri Keuangan Nomor 16 tahun 2017 tentang Permintaan Informasi dan/atau Bukti atau Keterangan terkait Akses Informasi Keuangan untuk Kepentingan Perpajakan tanggal 14 Juli 2017, permintaan IBK melalui Akasia yang belum diberi izin tertulis oleh Ketua Dewan Komisioner OJK dinyatakan tidak berlaku karena hendak menyeseuaikan dengan Perpu Nomor 1 tahun 2017, sehingga penerbitan surat permintaan IBK kembali dilakukan secara manual.

Terbitnya Perpu tentang akses informasi keuangan untuk kepentingan perpajakan ini disebut mempermudah administrasi penegakan hukum perpajakan. Menurut Kasi Penagihan, Perpu ini memberikan dampak bagi output maupun outcome seksi penagihan. Dari segi output berupa surat-surat yang diperlukan menjadi lebih mudah karena hanya memerlukan tandatangan kepala kantor, sayangnya dari segi outcome berupa penyelesaian proses dan terjadi pembayaran rupanya kurang memberikan dampak yang signifikan.

Kemudian pada tahun 2020, tepatnya tanggal 27 November pemerintah melalui Kementerian Keuangan menerbitkan PMK Nomor 189 tahun 2020 tentang Tata Cara Pelaksanaan Penagihan Pajak atas Jumlah Pajak yang Masih Harus Dibayar yang sekaligus mencabut KMK nomor 563 tahun 2000. PMK ini mengakomodir seluruh tindakan penagihan pajak aktif, termasuk tindakan pemblokiran dan menyederhanakan proses administrasinya

\subsection{Mengidentifikasi Kendala yang Timbul selama Proses Pemblokiran}

Menurut hasil wawancara, proses pemblokiran dan penyitaan harta kekayaan penanggung pajak yang tersimpan di bank dalam rangka penagihan pajak di KPP Pratama Madiun mengalami beberapa kendala, diantaranya:

a. Penanggung Pajak meninggal dunia

b. Penanggung pajak bangkrut/pailit sehingga atas utang pajak yang diterbitkan kesulitan untuk dilakukan tindakan penagihan pajak

c. Terjadi perubahan akta pada saat proses pemeriksaan maupun penagihan pajak.

d. Bank memenuhi pemblokiran rekening tetapi dilakukan tidak seketika

e. Ketidaktahuan ketentuan pemblokiran oleh Bank

f. Adanya ketidakseragaman pemahaman terkait prosedur pemblokiran oleh bank atas permintaan DJP

g. Adanya perbedaan ketentuan administrasi antara DJP dan perbankan

Dalam pelaksanaan pemblokiran, jurusita menyatakan bahwa perekaman realisasi tindakan blokir dilakukan apabila penanggung pajak terdaftar sebagai nasabah bank dan terdapat saldo di rekeningnya sehingga bank membuat Berita Acara (BA) Pemblokiran. Secara sederhana, data permintaan blokir dan realisasinya (dibuktikan dengan adanya BA Blokir) di KPP Pratama Madiun disajikan dalam grafik berikut: 
Grafik 1 Data jumlah permintaan blokir dan yang dijawab oleh Bank

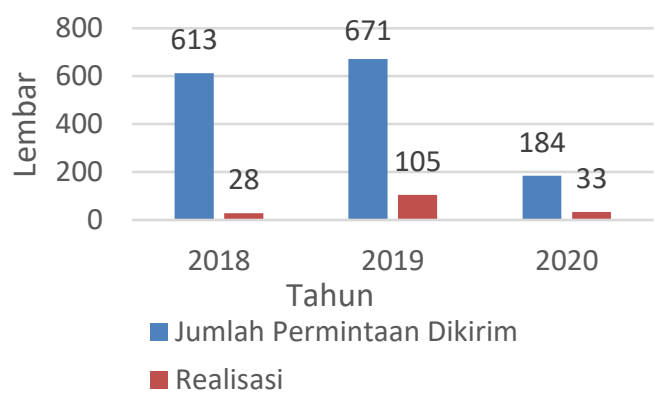

Sumber: Seksi Penagihan KPP Pratama Madiun (2021)

Perhitungan permintaan blokir dilakukan untuk tiap surat permintaan yang dikirimkan ke Bank. Berdasarkan wawancara dengan kasi penagihan, pengiriman permintaan blokir dilakukan dengan cara "jala ikan", yaitu untuk setiap satu wajib pajak yang diblokir maka akan dikirimkan surat permintaan blokir ke seluruh perbankan di wilayah kerja KPP Pratama Madiun. Dari Grafik 1 dapat dilihat bahwa dalam rentang waktu tiga tahun tersebut di tahun 2018 dan 2019 jumlah permintaan blokir yang dikirim sangat banyak dan menurun di tahun 2020 . Hal ini disebabkan oleh jumlah wajib pajak layak blokir di tahun 2018 dan 2019 lebih banyak dibandingkan tahun 2020. Namun ternyata realisasi blokir tidak selalu berbanding lurus dengan jumlah permintaan yang dikirim. Persentase pemenuhan permintaan blokir ini secara ringkas dapat digambarkan melalui grafik berikut:

Grafik 2 Persentase pemenuhan permintaan blokir oleh Bank

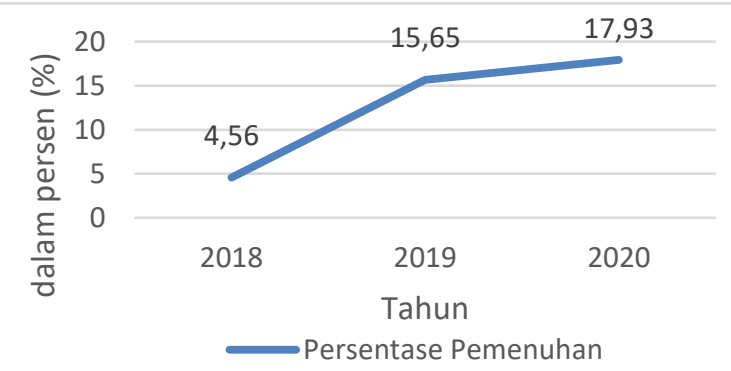

Sumber: Diolah Penulis (2021)

Dari Grafik 2 dapat dilihat bahwa persentase realisasi blokir dari tahun 2018 hingga tahun 2020 mengalami peningkatan, padahal di tahun 2020 jumlah permintaan yang dikirim justru sangat sedikit jika dibandingkan tahun 2018 dan 2019. Perbandingan terbalik ini dapat terjadi karena banyaknya variabel yang mempengaruhi pemenuhan permintaan blokir, jurusita menyatakan bahwa adanya variabel itikad baik penanggung pajak untuk membuat komitmen penyelesaian utang pajak, yaitu komitmen yang menyatakan bahwa wajib pajak mempunyai utang pajak dan bersedia menyelesaikan sebelum jatuh tempo, dan kooperatif atau tidaknya bank dalam merespon permintaan. Hal yang sama dapat terjadi pula dalam pencairan piutang pajak, realisasi blokir yang tinggi belum tentu menggambarkan pencairan pajak yang lebih besar, hal ini bergantung pada nominal pada surat paksa yang menjadi dasar pelaksanaan pemblokiran. Data mengenai pencairan utang pajak dari tindakan blokir yang telah terealisasi dapat dilihat di tabel berikut:

Tabel 1 Data pencairan pajak dari tindakan pemblokiran

\begin{tabular}{|c|c|c|c|}
\hline Tahun & $\begin{array}{c}\text { Permintaan } \\
\text { Blokir (Rp) }\end{array}$ & $\begin{array}{c}\text { Pencairan } \\
(\mathrm{Rp})\end{array}$ & $\begin{array}{c}\text { Persentase } \\
(\%)\end{array}$ \\
\hline 2018 & 2.128 .037 .081 & 346.233 .865 & 16,27 \\
\hline 2019 & 4.541 .199 .549 & 874.561 .520 & 19,25 \\
\hline 2020 & 4.134 .163 .278 & 802.381 .458 & 19,41 \\
\hline
\end{tabular}

Sumber : Seksi Penagihan KPP Pratama Madiun (2021)

Dari Tabel 1 dapat dilihat bahwa pencairan pajak dari tindakan pemblokiran oleh KPP Pratama Madiun mengalami peningkatan signifikan di tahun 2019, namun menurun di tahun 2020 baik dari nominal permintaan maupun pencairannya. Berdasarkan hasil wawancara dengan jurusita pajak, meskipun secara persentase sedikit meningkat, penerimaan pajak dari tindakan blokir turun sebesar Rp72.180.062 ini disebabkan oleh banyaknya wajib pajak yang membuat komitmen penyelesaian sebelum dilakukan blokir, dan adanya pandemi Covid-19 yang melatarbelakangi diterbitkannya beberapa peraturan oleh pemerintah mengenai relaksasi terkait perpajakan yang menyebabkan tertangguhnya tindakan penagihan aktif termasuk pemblokiran.

\subsection{Upaya Mencegah dan Mengatasi Kendala yang Timbul selama Proses Pemblokiran}

Dalam upaya untuk mencegah dan mengatasi kendala yang timbul selama proses pemblokiran, KPP Pratama Madiun berpedoman pada Surat Direktur Jenderal Pajak Nomor 20 tahun 2018 tanggal 12 Januari 2018 tentang Penegasan atas Pelaksanaan Pemblokiran, Pencegahan, dan Penyanderaan, serta melakukan tindakan-tindakan lain yang diperlukan. Adapun upaya pencegahan kendala yang dilakukan adalah:

a. Melakukan validasi untuk memastikan bahwa ketetapan pajak yang menjadi dasar timbulnya piutang pajak adalah benar

b. Melakukan validasi untuk memastikan bahwa ketetapan pajak yang menjadi dasar timbulnya piutang pajak sudah memiliki kekuatan hukum tetap (inkracht) dan telah diterbitkan dan disampaikan surat paksa

c. Memastikan bahwa tindakan penagihan aktif telah dilakukan sesuai dengan prosedur dan langkahlangkah yang diatur dalam ketentuan yang berlaku. Upaya pada huruf $a, b$, dan c ini dilakukan untuk mencegah adanya sengketa pajak di kemudian hari.

d. Memastikan bahwa upaya friendly collection secara persuasif kepada wajib pajak atau penanggung pajak telah dilakukan

e. Melakukan konsinyering atau harmonisasi ketentuan dengan perbankan. Upaya ini dilakukan untuk mencegah adanya ketidakseragaman pemahaman, perbedaan ketentuan administrasi, hingga ketidaktahuan ketentuan mengenai pemblokiran 
f. Membuat Surat Pernyataan atau Berita Acara Penyelesaian utang pajak bermeterai untuk merekam seluruh itikad baik dan kesanggupan wajib pajak dalam menyelesaikan utang pajak

g. Melakukan pemblokiran di Sistem Administrasi Badan Hukum (SABH) untuk mencegah adanya perubahan kepengurusan selama proses penagihan

Sedangkan upaya yang dilakukan oleh KPP

Pratama Madiun untuk mengatasi kendala yang timbul adalah:

a. Melakukan identifikasi dan profiling ulang atas penanggung pajak yang bertanggung jawab atas pembayaran seluruh piutang pajak yang telah divalidasi sebelumnya sesuai ketentuan dalam Pasal 32 UU KUP. Selain untuk mencegah adanya sengketa, upaya ini juga dilakukan ketika penanggung pajak meninggal dunia, bangjrut/pailit.

b. Melibatkan intelijen yang ada di Kanwil DJP dan jika diperlukan dapat berkoordinasi dengan Direktorat Intelijen Perpajakan dalam rangka melakukan identifikasi dan profiling atas penanggung pajak

c. Melakukan pemeriksaan tujuan lain dalam rangka penagihan pajak dalam rangka melaksanakan ketentuan dalam Pasal 32 UU KUP

d. Melakukan penelusuran asset bekerjasama dengan intelijen pada Kanwil DJP untuk memastikan bahwa wajib pajak dan penanggung pajak yang diusulkan memiliki potensi asset yang dapat digunakan untuk pelunasan utang pajak

e. Membuat laporan testimonial kronologis kejadian yang menjelaskan ketidak-kooperatif-an bank dan dikirimkan ke Otoritas Jasa Keuangan (OJK). Upaya ini dilakukan jika bank tidak memenuhi ketentuan pemblokiran, termasuk tidak memblokir secara seketika atau tidak kooperatif selama proses pemblokiran.

\section{KESIMPULAN DAN SARAN}

Tindakan pemblokiran dalam rangka penagihan pajak oleh KPP Pratama Madiun telah dilaksanakan sesuai dengan peraturan perundang-undangan yang berlaku. KPP Pratama Madiun melaksanakan pemblokiran sesuai KMK Nomor 563 tahun 2000 tentang Pemblokiran dan Penyitaan Harta Kekayaan Penanggung Pajak yang Tersimpan pada Bank dalam rangka Penagihan Pajak dengan Surat Paksa, Peraturan Direktur Jenderal Pajak Nomor 24 tahun 2014 tentang Tata Cara Pelaksanaan Pemblokiran dan Penyitaan Harta Kekayaan Penanggung Pajak yang Tersimpan pada Bank dalam rangka Penagihan Pajak dengan Surat Paksa. Selain itu juga melaksanakan ketentuan yang terdapat dalam PMK Nomor 189 tahun 2020 tentang Tata Cara Pelaksanaan Penagihan Pajak atas Jumlah Pajak yang Masih Harus Dibayar yang sekaligus mencabut KMK Nomor 563 tahun 2000.

Kendala yang timbul selama proses pemblokiran dalam rangka penagihan pajak secara umum berasal dari sisi penanggung pajak dan dari sisi perbankan. Selain itu, di tahun 2020 terjadi kendala lain yang berada diluar kuasa penanggung pajak, bank, maupun jurusita, yaitu adanya pandemi Covid-19 yang mendasari terbitnya peraturan yang menangguhkan pelaksanaan pemblokiran.

Dalam upaya mencegah dan mengatasi kendala selama proses pemblokiran, telah dilakukan upaya sesuai Surat Direktur Jenderal Pajak Nomor 20 tahun 2018 tanggal 12 Januari 2018 tentang Penegasan atas Pelaksanaan Pemblokiran, Pencegahan, dan Penyanderaan, yang secara umum menekankan pentingnya melakukan validasi dan profiling terhadap wajib pajak dengan tepat. Selain itu, juga dilakukan upaya lain yang dianggap perlu sesuai diskresi Seksi Penagihan dan Jurusita Pajak seperti konsinyering ketentuan dengan perbankan.

Berkaitan dengan pelaksanaan pemblokiran dan penyitaan harta kekayaan yang tersimpan di Bank, beberapa saran yang dapat penulis berikan untuk lembaga keuangan adalah agar bersikap kooperatif dengan jurusita pajak terkait pelaksanaan pemblokiran dengan memberikan respon yang cepat dan terbuka sesuai Perpu Nomor 1 tahun 2017 tentang Akses Informasi Keuangan untuk Kepentingan Perpajakan, untuk Direktorat Jenderal Pajak adalah agar lebih menegaskan mengenai aturan pemblokiran dan penyitaan harta kekayaan yang tersimpan di bank agar pelaksanaannya menjadi selaras antara DJP dan bank, serta saran untuk penelitian selanjutnya adalah agar membahas lebih lanjut mengenai prosedur keterbukaan informasi keuangan dari sisi lembaga jasa keuangan.

\section{IMPLIKASI DAN KETERBATASAN}

Implikasi dari penelitian ini adalah untuk menambah pengetahuan secara teori maupun implementasi mengenai pelaksanaan pemblokiran dalam rangka penagihan pajak sesuai peraturan perundang-undangan, menjadi pertimbangan bagi KPP Pratama Madiun dalam mendiskresi kebijakan yang diperlukan dalam berbagai kondisi di lapangan, serta menjadi bahan evaluasi bagi perbankan mengenai pentingnya pemenuhan permintaan informasi keuangan untuk kepentingan perpajakan. Penelitian ini juga memiliki keterbatasan, yaitu hanya dilakukan di Kantor Pelayanan Pajak Pratama Madiun dengan ruang lingkup tahun 2018-2020, sehingga hasil penelitian hanya mencerminkan kondisi yang ada di wilayah kerja KPP Pratama Madiun yang terjadi pada tahun tersebut.

\section{DAFTAR PUSTAKA (REFERENCES)}

Astini, N. K. (2019). Pentingnya Literasi Teknologi Informasi Dan Komunikasi Bagi Guru Sekolah Dasar Untuk Menyiapkan Generasi Milenial. Prosiding Seminar Nasional Dharma Acarya ke-1: Tantangan dan Peluang Dunia Pendidikan di Era 4.0, 1(1), 113120. Diambil dari https://stahnmpukuturan.ac.id /jurnal/index.php/dharmaacarya/article/view/194 $/ 187$

Bandiyono, A., \& Karimah, D. A. (2021). Implementasi atas Pemberian Informasi dan Bukti/Keterangan dalam Hal Akses Informasi Keuangan untuk 
Kepentingan Perpajakan. Jurnal IImiah MEA, 5(1), 563.

Chloe Norris, N. W. (2017). Guardianship Manual. Pengadilan Tinggi Daerah Shonomish. Diambil kembali dari https://www.pdfdrive.com/ guardianship-manual-e43810111.html

Direktorat Jenderal Pajak. (2019). Peningkatan Kapasitas secara Berkesinambungan melalui Penguatan Tata Kelola Data dan Teknologi Informasi Perpajakan. Laporan Tahunan DIrektorat Jenderal Pajak, Jakarta Selatan. Diambil dari https://www.pajak.go.id/sites/ default/files/202012/Laporan\%20Tahunan\% 20DJP\%202019\%20\%2OINDONESIA.pdf

Frida, C. V. (2020). Hukum Pajak di Indonesia: Pengantar atau Dasar-Dasar Perpajakan. Garudhawacana. Diambil dari https://books.google.co.id/ books?id=2Gr-DwAAQBAJ \&pg=PA214\&dq=

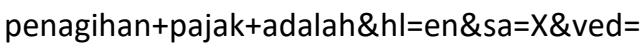
2ahUKEwiop6TEroTvAhUCXSsKHcIWBvcQ6AEwA3 oECAUQAg\#v=onepage $\& q=$ penagihan $\% 20$ pajak\% 20adalah $\& \mathrm{f}=$ false

Kemenkeu. (2020, Januari 8). Kementerian Keuangan Republik Indonesia. Diambil Desember 9, 2020, dari https://www.kemenkeu.go.id/publikasi/ berita/ini-realisasi-penerimaan-negara-dipenghujung-2019/

Kementerian Keuangan Republik Indonesia. (2019). Laporan Kinerja Direktorat Jenderal Pajak. Jakarta Selatan.

Nasution, H., \& Aliffioni, A. (2018). Analisis Efektivitas Penagihan Pajak Dengan Surat Paksa Dan Penyitaan Untuk Meningkatkan Penerimaan Pajak Pada Kantor Pelayanan Pajak Pratama Bekasi Utara. Jurnal IImiah Wahana Akuntansi, 13(2), 129-142.

Nota Kesepahaman SP 22/DKNS/OJK/III/2017 antara Otoritas Jasa Keuangan dengan Direktorat Jenderal Pajak tentang Kerja Sama dalam Bidang Pengaturan, Pengawasan dan Penegakan Hukum serta Perlindungan Konsumen di Sektor Jasa Keuangan

Peraturan Bank Indonesia Nomor 2 tahun 2000 tentang Persyaratan dan Tata Cara Pemberian Perintah atau Izin Tertulis Membuka Rahasia Bank

Peraturan Direktur Jenderal Pajak Nomor 24 tahun 2014 tentang Tata Cara Pelaksanaan Pemblokiran dan Penyitaan Harta Kekayaan Penanggung Pajak yang Tersimpan pada Bank dalam rangka Penagihan Pajak dengan Surat Paksa

Peraturan Menteri Keuangan Nomor 70 tahun 2017 sebagaimana telah diubah dengan Peraturan Menteri Keuangan Nomor 19 tahun 2018 tentang Petunjuk Teknis mengenai Akses Informasi Keuangan untuk Kepentingan Perpajakan

Peraturan Menteri Keuangan Nomor 189 tahun 2020 tentang Tata Cara Pelaksanaan Penagihan Pajak atas Jumlah Pajak yang Masih Harus Dibayar

Peraturan Pemerintah Pengganti Undang-Undang Nomor 1 tahun 2017 tentang Akses Informasi Keuangan untuk Kepentingan Perpajakan
PPID Kominfo. (2017, Juni 17). Madiun Kota Pendekar. Dipetik Desember 24, 2020, dari https://madiunkota.go.id/2017/06/17/kotamadiun-terpilih-sebagai-wilayah-ke-4-pilihan-biperesmian-kas-titipan-bi-di-wilayah-madiun/

Qodri, A. (2014). Harta Benda dalam Perspektif Hukum Islam. Jurnal Penelitian Universitas Jambi Seri Humaniora, 16(1), 11-18. Diambil kembali dari https://media.neliti.com/media/publications/434 55-ID-harta-benda-dalam-perspektif-hukumislam.pdf

Santoso, B. C. (2020). Akibat Adanya Keterbukaan Informasi Pajak Pasca Dikeluarkannya Perppu Nomor 1 Tahun 2017 Tentang Akses Informasi Keuangan Untuk Kepentingan Perpajakan. Mimbar Keadilan, 13(1), 13.

Sjamsuddin, R. M. (2015, Oktober). Perlindungan Hukum Bagi Nasabah Dalam Bentuk Rahasia Bank. Lex Privatum, lii(4).

Somantri, G. R. (2005). Memahami Metode Kualitatif. MAKARA, SOSIAL HUMANIORA, 9(2), 57-65. Diambil dari https://scholarhub.ui.ac.id/ cgi/viewcontent.cgi?article=1255\&context=hubsa sia

Surat Direktur Jenderal Pajak Nomor 20 tahun 2018 tentang Penegasan atas Pelaksanaan Pemblokiran, Pencegahan, dan Penyanderaan

Surat Edaran Menteri Keuangan Nomor 16 tahun 2017 tentang Permintaan Informasi dan/atau Bukti atau Keterangan terkait Akses Informasi Keuangan untuk Kepentingan Perpajakan

Sulistiriyanto, H. (2011). Penafsiran dan Prosedur Sita atas Harta Kekayaan Wajib Pajak menurut Peraturan Perbankan di Indonesia. Perspektif, XVI(1). Diambil kembali dari https://ejournal.uwks.ac.id/myfiles/20120753092 1134643/3.pdf

Susi Zulvina, I. A. (2017). Pengantar Hukum Pajak. Tangerang Selatan: PKN STAN.

Wildan, M. (2020, September 25). DDTC News: Trusted Indonesian Tax News Portal. Dipetik Desember 12, 2020, dari https://news.ddtc.co.id/hanya-43permintaan-data-dari-ditjen-pajak-yang-dipenuhiperbankan-24228?page_y=888. 888916015625 